Chi, Tailan. (1997) The Structuring of Interfirm Exchanges in Business Know-How: Evidence From International Collaborative Ventures. Managerial and Decision Economics, 18, 279-294.

Publisher's Official Version: <http://dx.doi.org/10.1002/(SICI)1099-1468(199706)18:4<279::AID-MDE826>3.0.CO;2-S>.

Open Access Version: http://kuscholarworks.ku.edu/dspace/

[This document contains the author's accepted manuscript. For the publisher's version, see the link in the header of this document.]

\title{
The Structuring of Interfirm Exchanges in Business Know-How: Evidence from International Collaborative Ventures
}

\author{
By Tailan Chi and Thomas W. Roehl \\ The University of Kansas and The University of Illinois, Urbana-Champaign
}

\section{Paper citation:}

Chi, Tailan. (1997) The Structuring of Interfirm Exchanges in Business Know-How: Evidence From International Collaborative Ventures. Managerial and Decision Economics, 18, 279-294.

\begin{abstract}
:
This study investigates the effects of transaction cost considerations on the apportionment of residual bearing and the assignment of managerial control between two firms involved in the exchange of business know-how. Data were collected from contractual agreements between multinational enterprises and indigenous firms that formed collaborative ventures in developing countries. A simultaneous-equation model was employed to test hypotheses that were derived under a theoretical framework based on the new institutional economics. The empirical results are supportive of the hypotheses.
\end{abstract}


Chi, Tailan. (1997) The Structuring of Interfirm Exchanges in Business Know-How: Evidence From International Collaborative Ventures. Managerial and Decision Economics, 18, 279-294.

Publisher's Official Version: <http://dx.doi.org/10.1002/(SICl)1099-1468(199706)18:4<279::AID-MDE826>3.0.CO;2-S>.

Open Access Version: http://kuscholarworks.ku.edu/dspace/

\title{
The Structuring of Interfirm Exchanges in Business Know-How:
}

\section{Evidence from International Collaborative Ventures}

\author{
Tailan Chi \\ University of Wisconsin-Milwaukee \\ P. O. Box 742 \\ Milwaukee, WI 53201-0742 \\ Tel: (414)229-5429 \\ Fax: (414)229-6957 \\ E-mail: chi@csd.uwm.edu \\ Thomas W. Roehl \\ University of Illinois, Urbana-Champaign \\ 350 Commerce West Building \\ 1206 S. Sixth Street \\ Champaign, IL 61820-6980 \\ Tel: (217)333-0147 \\ Fax: (217)244-7969 \\ E-mail: t-roehl@uiuc.edu
}

The authors wish to recognize an anonymous referee whose suggestions resulted in significant improvements in the quality of this paper. They also wish to thank Ron Dombrow and Jinqi Liu for research assistance.

Accepted for publication in Managerial and Decision Economics, 18, pp. 279-294, 1997. 
Publisher's Official Version: <http://dx.doi.org/10.1002/(SICI)1099-1468(199706)18:4<279::AID-MDE826>3.0.CO;2-S>.

Open Access Version: http://kuscholarworks.ku.edu/dspace/

\title{
The Structuring of Interfirm Exchanges in Business Know-How:
}

\section{Evidence from International Collaborative Ventures}

\author{
ABSTRACT \\ This study investigates the effects of transaction cost considerations on the apportionment of \\ residual bearing and the assignment of managerial control between two firms involved in the \\ exchange of business know-how. Data were collected from contractual agreements between \\ multinational enterprises and indigenous firms that formed collaborative ventures in developing \\ countries. A simultaneous-equation model was employed to test hypotheses that were derived \\ under a theoretical framework based on the new institutional economics. The empirical results \\ are supportive of the hypotheses.
}


Chi, Tailan. (1997) The Structuring of Interfirm Exchanges in Business Know-How: Evidence From International Collaborative Ventures. Managerial and Decision Economics, 18, 279-294.

Publisher's Official Version: <http://dx.doi.org/10.1002/(SICI)1099-1468(199706)18:4<279::AID-MDE826>3.0.CO;2-S>.

Open Access Version: http://kuscholarworks.ku.edu/dspace/

\section{INTRODUCTION}

A number of authors have suggested that exchange relationships can be analyzed along an institutional continuum ranging from arm's length deals on the market to internal transactions within the same firm (Gatignon and Andeson 1988, Joskow 1985, Pisano 1989, Williamson 1985). The exchange arrangements that fall between the two extremes of this continuum, such as licensing agreements, management contracts and joint ventures, are often referred to as hybrid or intermediate institutions. Although such intermediate institutions tend to be very complex and can have infinite variations, the literature of the new institutional economics has highlighted two structural dimensions along which their economic attributes are defined. One dimension concerns how the exchange parties receive their respective payoffs from the exchange-a question that has received most attention from models of contracting under imperfect performance measurement. The other dimension concerns how the exchange parties partition the control rights to their joint or interdependent operations - a question that has received most attention from models of contracting under asset specificity.

Despite the theoretical distinction between these two structural dimensions, they are rarely distinguished in the existent empirical work on the choice of institutional arrangements in interfirm exchanges. Most commonly, the structure of such arrangements is operationalized as a single variable that is a priori correlated with both of the structural dimensions. The most often used variable is the equity ownership status of the exchange parties, which is generally specified in a complex contract with clauses affecting both the compensation and control dimensions of the exchange. ${ }^{1}$ Although this approach can help get around certain informational and statistical difficulties (to be discussed in more detail later), it subjects the interpretation of the empirical 
Chi, Tailan. (1997) The Structuring of Interfirm Exchanges in Business Know-How: Evidence From International Collaborative Ventures. Managerial and Decision Economics, 18, 279-294.

Publisher's Official Version: <http://dx.doi.org/10.1002/(SICI)1099-1468(199706)18:4<279::AID-MDE826>3.0.CO;2-S>.

Open Access Version: http://kuscholarworks.ku.edu/dspace/

findings to an additional measure of ambiguity. For instance, even if a statistical relationship is found between a party’s equity ownership status and some characteristic of the exchange, it is still not clear whether what matters is the method of payment or the means of control.

In this study, we attempt to conduct a two-dimensional analysis of interfirm arrangements for the exchange of business know-how, such as production and marketing expertise. The data used in our analysis were collected from collaborative ventures between multinational enterprises (MNEs) and local firms in developing countries. Section II presents the theoretical framework under which this study is conducted. Section III derives a number of hypotheses that relate the two structural dimensions to some observable features of such collaborative ventures. Section IV explains the empirical methods employed in this study. Section V presents and discusses the empirical results. Section VI concludes the paper.

\section{THE STRUCTURING OF EXCHANGES UNDER IMPERFECT CONTRACTING}

In this paper, we use the expression "business know-how" to refer to any knowledge that is valuable to a firm's operations, including not only such primary activities as production and marketing but also such supportive activities as labor and government relations. The literature on imperfect competition and growth of the firm has identified a number of attributes that tend to characterize the business know-how that a firm possesses. First, in order for any know-how to be valuable, it must contain a significant amount of proprietary knowledge (Lippman and Rumelt 1982). Second, the knowledge is often spread across multiple employees of the firm, each of whom only possesses a part of the total (Nelson and Winter 1982). Third, the knowledge often consists of many tacit elements that are difficult to articulate and thus require extensive hands-on

\footnotetext{
${ }^{1}$ See, for example, the empirical studies of Davidson and McFetridge (1985), Gatignon and Andeson (1988), GomesCasseres (1989), Hennart (1991), Pisano (1989) and Shan (1990).
} 
Chi, Tailan. (1997) The Structuring of Interfirm Exchanges in Business Know-How: Evidence From International Collaborative Ventures. Managerial and Decision Economics, 18, 279-294.

Publisher's Official Version: <http://dx.doi.org/10.1002/(SICl)1099-1468(199706)18:4<279::AID-MDE826>3.0.CO;2-S>.

Open Access Version: http://kuscholarworks.ku.edu/dspace/

training in order to be fully transferred from one firm to another (Penrose 1959, Teece 1982).

Hence, in order to consummate an interfirm exchange of business know-how that possesses these attributes, there must be an extended period of close interactions among many employees of the two firms. The exchange relationship between the firms, therefore, is likely to be complex and subject to a variety of contracting problems.

Contracting problems can arise both ex ante and ex post. Because ex ante difficulties in contracting tend to reduce the completeness of any contract reached, they often form part of the reasons for ex post difficulties in managing the resultant contractual relationship. ${ }^{2}$ Incomplete contracting can result from two types of information deficiencies ex ante. One is the uncertainty of future contingencies on which the actions of the contracting parties must depend, because such uncertainty can make it economically infeasible to specify many of the actions to be taken in the duration of the contract (Williamson 1975). In the case of exchanges in technological know-how, for example, it is often very difficult to anticipate the nature and extent of possible future improvements on the present know-how, let alone contracting on their potential applications ex ante. The other type of information deficiency that often gives rise to incomplete contracting (especially in the exchange of business know-how) is the possession of asymmetric information by the parties involved in the exchange (McManus 1975). When the know-how being traded is proprietary and contains many tacit elements, the buyer of the know-how or the service thereof will know much less than the seller about what the seller should do to fulfill its part of the

\footnotetext{
${ }^{2}$ In an interfirm exchange involving the transfer of proprietary technology, for instance, the transferee by definition does not know exactly how the transfer process should proceed, and the contract between the two parties are hence necessarily incomplete. Although the transferee can try to stipulate in the contract that the transferor take some specified actions (such as send a certain number of engineers to the venture and give the transferee's personnel a certain period of training), a complete transfer of the technology is likely to entail many detailed steps that the transferee does not know of. In order to cover these ex ante nonspecifiable actions expected from the transferor, the two parties may have to employ such vaguely worded contractual clauses as "reveal all relevant information about
} 
Chi, Tailan. (1997) The Structuring of Interfirm Exchanges in Business Know-How: Evidence From International Collaborative Ventures. Managerial and Decision Economics, 18, 279-294.

Publisher's Official Version: <http://dx.doi.org/10.1002/(SICI)1099-1468(199706)18:4<279::AID-MDE826>3.0.CO;2-S>.

Open Access Version: http://kuscholarworks.ku.edu/dspace/

bargain. Even though the seller may possess the appropriate information, it is unlikely to have any incentive to put the information in the contract since the buyer has no means to verify its sufficiency or correctness.

Incomplete contracting leaves potential opportunities for the exchange parties to gain at the expense of the other in the contract implementation process. One can analytically distinguish between two kinds of ex post opportunism, moral hazard and holdup, which tend to be amenable to two different types of structural remedies (Alchian and Woodward 1988).

\section{A. Moral Hazard and Apportionment of Residual Claimancy}

Moral hazard refers to the opportunism of shirking in situations where the actions of a contracting party can not be perfectly observed or verified. Interfirm exchanges of business know-how are often characterized by conditions that subject both parties to this kind of opportunistic behavior (Hennart 1988). First, both parties may face significant difficulty in monitoring the actions of the other due to their lack of knowledge about each other's expertise. Second, since the outcome of the exchange is generally under the influence of both parties as well as random factors beyond their control, the extent to which the outcome is attributable to a given party can also be easily subject to dispute. In the face of such double moral hazard, performance incentives for the two parties may have to be provided primarily through a compensation structure under which they each bear some of the residuals from their exchange (Barzel 1989). ${ }^{3}$ In a joint production or service operation run by two otherwise independent

the technology" and "do everything necessary to achieve the best possible operating results.” Because such vague performance measures are inevitably difficult to verify ex post, their enforcement is likely to be problematic. ${ }^{3}$ Contractual constraints may be more effective than residual claims in enforcing those aspects of knowledge transfer (such as delivery of documents specifying the type of machinery to be procured) that can be unambiguously spelled out in a contract to allow a court or an arbitrator to easily identify them as the MNE's obligations (Chi 1996). In this sense, contractual constraints and residual claims are complementary in dealing with the moral hazard problem in the 
Chi, Tailan. (1997) The Structuring of Interfirm Exchanges in Business Know-How: Evidence From International Collaborative Ventures. Managerial and Decision Economics, 18, 279-294.

Publisher's Official Version: <http://dx.doi.org/10.1002/(SICI)1099-1468(199706)18:4<279::AID-MDE826>3.0.CO;2-S>.

Open Access Version: http://kuscholarworks.ku.edu/dspace/

firms, the residuals from their exchange are generally reflected in the operation's accounting profit or equity stock.

Note that, in a bilateral exchange relationship, an increase in one party’s residual bearing necessarily means a decrease in the other party’s residual bearing (Holmstrom 1982). Since the extent of each party's residual bearing affects its incentive to perform in exchanges under double moral hazard, the apportionment of residual claimancy between the two parties influences the overall incentive structure of the contract. Theoretical models of such exchange relations suggest that the incentive-optimizing apportionment of residual claimancy depends on how measurable each party's performance is and how severely each party's shirking is likely to dissipate the gains from the exchange. Specifically, the optimal residual share is shown to be such that a greater extent of residual bearing be given to a party when that party’s performance is ceteris paribus less measurable or more important to the realization of the potential gains from the exchange (Chi 1996, Eswaran and Kotwal 1985).

The efficacy of residual claimancy in mitigating opportunism, however, is limited to the strength of the linkage between the opportunistic behavior in question and the residuals from the exchange. In interfirm exchanges of business know-how, certain opportunistic acts can cause a large wealth transfer between the two parties without having a comparable impact on the residual earnings from their joint operation. In the licensing of technology, for instance, the licenser can become vulnerable to the acts of ex post wealth expropriation by the licensee (Teece 1986). Typically, the licenser would restrict the geographical areas in which the licensee is allowed to sell its output produced under the license. But once the licensee acquires the technology, it may ignore any contractual restrictions in this regard and sell its output beyond the area designated in 
Chi, Tailan. (1997) The Structuring of Interfirm Exchanges in Business Know-How: Evidence From International Collaborative Ventures. Managerial and Decision Economics, 18, 279-294.

Publisher's Official Version: <http://dx.doi.org/10.1002/(SICI)1099-1468(199706)18:4<279::AID-MDE826>3.0.CO;2-S>.

Open Access Version: http://kuscholarworks.ku.edu/dspace/

the licensing agreement. Even without such blatant violation of the contract, the licensee may

still be able to expropriate additional wealth from the licenser by forcing favorable changes in the terms of the original contract via threats of noncooperation once it no longer relies on the licenser for the technological input. These acts of opportunism often can be more accurately characterized as holdup, and the hazards of their occurring generally can not be checked cost-effectively by the apportionment of the residuals from the joint operation of the two parties.

\section{B. Holdup and Assignment of Residual Control}

Holdup refers to the opportunism of expropriating wealth from one’s exchange partner in transactions that are characterized by a significant degree of asset specificity. It involves either a violation of some clearly specified agreements or a refusal to cooperate on issues that are left open or turn out to be unrealistically specified in existing contracts. Such expropriating activities cannot be fully anticipated during contract negotiation because their cost/benefit calculus is often uncertain ex ante and subject to change after the contract is negotiated (Klein 1992). In interfirm exchanges of business know-how, for instance, the discovery of an unexpected and significant new application of the know-how can spawn serious disputes between the exchange partners regarding their respective rights to profit from the new application. Furthermore, although the aim of holdup concerns the distribution of rents between the exchange partners, the activities undertaken for this end (such as bargaining and litigation) can consume significant amounts of economic resources (Crocker and Masten 1991, Goldberg and Erickson 1987). ${ }^{4}$ As neither the rents redistributed nor the resources dissipated via holdup activities are normally well reflected in 
Chi, Tailan. (1997) The Structuring of Interfirm Exchanges in Business Know-How: Evidence From International Collaborative Ventures. Managerial and Decision Economics, 18, 279-294.

Publisher's Official Version: <http://dx.doi.org/10.1002/(SICI)1099-1468(199706)18:4<279::AID-MDE826>3.0.CO;2-S>.

Open Access Version: http://kuscholarworks.ku.edu/dspace/

the residuals of the exchange, the apportionment of residual claimancy between the two parties in general can not provide a good remedy for this kind of ex post opportunism.

As articulated by Williamson (1975, 1985), the economically efficient remedy for holdup tends to be found in the control structure of the exchange arrangement, because it is the control of certain critical decisions that gives a party the ability to gain at the expense of its exchange partner. Grossman and Hart (1986) suggest that the rights of control over decisions in a bilateral exchange fall into two types, depending on whether a given decision is contractually designated ex ante as the purview of a particular party. Those decision rights that are not assigned ex ante to either party fall by default to the party that is designated in the contract as the owner of the exchange operation. In many interfirm arrangements, however, ownership to the exchange operation is shared between the two parties, and each of the parties holds some of the decisionmaking positions via their own personnel assigned to manage the joint operation. Although some important decisions do require consensus of the two parties in such an arrangement, many of the ex ante unspecified decisions are de facto made by whichever party holds the relevant managerial positions through its own personnel (Contractor 1985). Hence, the extent of control that a party holds over the decisions of the joint operation is largely determined by the extent to which that party controls the decision-making positions of the operation through staffing arrangements.

Grossman and Hart (1986) argued that the party holding the ownership or residual rights of control in a bilateral exchange can be expected to reap a greater gain from the exchange. We submit that greater residual control through staffing arrangements in a jointly owned exchange operation has a similar effect because such control represents not only opportunities to gain at the 
Chi, Tailan. (1997) The Structuring of Interfirm Exchanges in Business Know-How: Evidence From International Collaborative Ventures. Managerial and Decision Economics, 18, 279-294.

Publisher's Official Version: <http://dx.doi.org/10.1002/(SICI)1099-1468(199706)18:4<279::AID-MDE826>3.0.CO;2-S>.

Open Access Version: http://kuscholarworks.ku.edu/dspace/

expense of the other party but also means to curb potential opportunism by the other party. ${ }^{5}$ As

shown by Holmstrom and Milgrom (1990), efficient contracting will require the removal of

certain decision making discretion from an agent when it is too expensive to provide the right

incentives (such as via residual claimancy) for the agent to refrain from costly opportunism.

Since the two contracting parties in general both have the potential to engage in ex post

opportunism, the assignment of residual control in an interfirm exchange needs to balance the

holdup hazards posed by both parties. As pointed out by Masten (1988) and Klein (1992), an

adjustment in contract terms intended to reduce the holdup potential of one exchange party often

would increase the holdup potential of the other party. This trade-off in our view is particularly

important to the assignment of residual control in an interfirm exchange of business know-how

because greater control gives a party more opportunities to gain at the expense of the other and

leaves less opportunities for the other to do so. Since a given holdup hazard can often be lowered

by removing or reducing the potential offender's control over certain decisions, we can expect

that a party will be given less residual control when that party poses a particular holdup hazard. ${ }^{6}$

\begin{abstract}
${ }^{5}$ Grossman and Hart (1986) used the phrase "residual rights of control" to refer to decision-making prerogatives that are not contractually designated and thus are left to the owner of the exchange operation when the operation has only one owner. In this paper, we use the phrase "residual control" to refer to decision-making prerogatives that are not contractually restricted to either party but are effectively controlled by the party that holds the relevant managerial positions in the exchange operation when the operation is jointly owned by both of the parties involved.

${ }^{6}$ Masten (1988) suggested that the problem of optimal contracting in the face of holdup hazards can be formulated as one of minimizing the expected value dissipation resulting from the two parties' holdup activities. Klein (1992), in the meantime, formulated the problem as one of minimizing the sum of the two parties' expected gains from their respective holdup activities by noting that this formation will imply the minimization of transaction costs if the value dissipated from holdup is proportional to the value appropriable through holdup. We suggest that the proportionality assumption is not necessary for Klein's formulation to imply the minimization of transaction costs if the costs of negotiating the initial contract (including lost profit due to failure to reach a mutually beneficial agreement) are also taken into account. As suggested by Balakrishnan and Koza (1993), the negotiation of an interfirm arrangement is often plagued by the adverse selection problem due to information asymmetry between the two parties. Significant information asymmetry can exist regarding each party's valuation of their own reputation (or their "trustworthiness") and the circumstances that will likely cause them to engage in ex post opportunism. If the two parties can negotiate, at a relative low cost, contract terms that effectively reduce the threats of ex post opportunism, they may be able to significantly cut down the ex ante bargaining costs (including the value lost in the case of their failure to reach an
\end{abstract}


Chi, Tailan. (1997) The Structuring of Interfirm Exchanges in Business Know-How: Evidence From International Collaborative Ventures. Managerial and Decision Economics, 18, 279-294.

Publisher's Official Version: <http://dx.doi.org/10.1002/(SICI)1099-1468(199706)18:4<279::AID-MDE826>3.0.CO;2-S>.

Open Access Version: http://kuscholarworks.ku.edu/dspace/

We can summarize the analysis of this section in two propositions regarding the structure of interfirm exchanges in business know-how. First, a party is likely to hold greater residual

claimancy in the exchange operation ceteris paribus when its performance is less measurable or more important to the realization of the potential gains from the exchange. Second, a party is likely to hold greater residual control in the exchange operation ceteris paribus when it is more vulnerable to holdup hazards posed by the other party. Based on these two propositions, we will in the next section derive a number of testable hypotheses about the structure of collaborative ventures between a multinational enterprise and an indigenous firm in developing countries.

\section{HYPOTHESES}

The objective of this section is to scrutinize the relations of certain observable variables with the apportionment of residual claimancy and the assignment of residual control between two participants in an international collaborative venture (ICV). Our examination will focus on ICVs that involve the transfer of some technological know-how from a multinational enterprise (MNE) to a local firm of the host country. The literature on ICVs suggests two reasons for such interfirm arrangements (Beamish 1988, Contractor and Lorange 1987). The most important reason is the presence of complementarity between the resources of the two firms. Although the MNE's technological know-how often constitutes the principal rent-earning resource of the venture, the local firm may also possess some country-specific marketing or management skills that the MNE lacks and can not replicate in a cost-effective fashion. Without such resource complementarity, the MNE in general would not see any reason to share its know-how with a local firm unless the local government requires this as a condition for doing business in the host country. 
Chi, Tailan. (1997) The Structuring of Interfirm Exchanges in Business Know-How: Evidence From International Collaborative Ventures. Managerial and Decision Economics, 18, 279-294.

Publisher's Official Version: <http://dx.doi.org/10.1002/(SICI)1099-1468(199706)18:4<279::AID-MDE826>3.0.CO;2-S>.

Open Access Version: http://kuscholarworks.ku.edu/dspace/

An effective transfer of the know-how in question from the MNE to the local firm would normally entail the provision of some training for the local firm’s personnel, except in cases where the know-how is simple enough to be fully coded in a highly intelligible technical manual. Although the two parties can negotiate certain contractual stipulations on technical training (such as time, place and duration), the detailed design and implementation of a training program has to be left to the MNE's discretion due to the local firm’s lack of knowledge (Teece 1982). Hence, such discretionary training is likely to be one of the MNE's resource contributions that needs to be motivated through considerable residual claimancy (Chi 1996). As explained by Contractor (1985), the basic economic rationale for an MNE to train locals is to reduce the use of the more expensive expatriates. So, in contrast to its effect on residual claimancy, more training from the MNE is likely to result in more managerial and technical positions being held the local firm’s personnel. ${ }^{7} \mathrm{We}$, therefore, have the following hypothesis regarding how the MNE's provision of discretionary training affects the partition of claimancy and control in an ICV.

H1. The MNE is likely to bear more residual claimancy but hold less residual control in the venture ceteris paribus when it is expected to provide more discretionary training for the local firm’s personnel.

The extent of knowledge transfer from the MNE to the local firm depends on not only the MNE's effort in teaching but also the local firm's capacity of learning. When the local firm has more accurate information about the MNE’s technological know-how, it will be able to negotiate more effective constraints on the MNE's discretion in training and obtain more knowledge from the MNE by asking relevant questions in the training process (Kogut 1988). Hence, for the same

\footnotetext{
${ }^{7}$ As Williamson (1985: 90-95) pointed out, the optimal institutional choice should be one that minimizes the sum of production and governance costs.
} 
Chi, Tailan. (1997) The Structuring of Interfirm Exchanges in Business Know-How: Evidence From International Collaborative Ventures. Managerial and Decision Economics, 18, 279-294.

Publisher's Official Version: <http://dx.doi.org/10.1002/(SICI)1099-1468(199706)18:4<279::AID-MDE826>3.0.CO;2-S>.

Open Access Version: http://kuscholarworks.ku.edu/dspace/

discretionary effort from the MNE, one can expect more of its know-how to be transferred as the local firm is more capable of exacting information from the MNE. One condition that tends to make the local firm better able to "learn" is prior experience in a business that is technologically similar to that of the MNE's unit involved in the venture (Hamel, Doz and Prahalad 1989). Such similarity can be expected to lessen the need for the use of residual claimancy as inducement for the MNE to assert more effort in training. In the meantime, the local firm's capacity to absorb the MNE's know-how could also raise the MNE's concern over losing its bargaining leverage and thus becoming vulnerable to holdup by the local firm (Beamish and Banks 1987). Such concern could then prompt the MNE to bargain for greater residual control during the initial negotiation of the venture's governance structure. By controlling certain functions of the venture through its own personnel, the MNE may be able to withhold a key subset of its know-how and retain more effective control over the use of its rent-earning assets (Geringer and Herbert 1989). We can, therefore, derive the following hypothesis from the above analysis.

H2. The MNE is likely to bear less residual claimancy but hold more residual control in the venture ceteris paribus when the local firm's business is more similar to the business of the MNE's unit involved in the venture.

A necessary condition for the local firm to be able to misappropriate the rents from the MNE's technological know-how is the existence of imperfections in the prevailing legal regime governing industrial property rights (namely, patents, trademarks, copyrights and trade secrets). The more imperfect the legal regime is, the higher is the risk for such misappropriation to occur and the greater is the benefit that the MNE can derive from retaining control over the decisions on the venture's operation (Teece 1986). However, it is often costly for the MNE to expand its 
Chi, Tailan. (1997) The Structuring of Interfirm Exchanges in Business Know-How: Evidence From International Collaborative Ventures. Managerial and Decision Economics, 18, 279-294.

Publisher's Official Version: <http://dx.doi.org/10.1002/(SICI)1099-1468(199706)18:4<279::AID-MDE826>3.0.CO;2-S>.

Open Access Version: http://kuscholarworks.ku.edu/dspace/

control over an ICV by using more of its own personnel to manage the venture due to large compensation differentials between expatriates and locals in developing countries. Since the extent of protection afforded to industrial property rights varies from country to country in the developing world (Benko 1987), the trade-off that the MNE faces in appraising the control structures of its ICVs is also likely to vary from one country to another. Hence,

H3. The MNE is likely to hold a higher degree of residual control in the venture ceteris paribus when the protection that the host country’s legal regime affords to industrial property rights is perceived to be weaker.

As alluded to earlier, the local firm is also likely to possess some expertise that the MNE lacks in marketing the venture's output or managing labor and government relations in the host country. Because such input contributions from the local firm are often difficult for the MNE to monitor, they may need to be motivated through considerable residual claimancy (Hennart 1988). The country-specific marketing skills of the local firm will not be so important to the venture's economic performance, however, if much of the venture's output is sold through the MNE's own corporate network, either locally or abroad, without the local firm’s involvement. Hence, we can expect that the benefit from apportioning residuals to the local firm will diminish as more of the venture's output is marketed through the MNE's own network. In the meantime, as more of the venture's output enters the MNE's corporate system (either sold to its own customers or used as inputs in its own production facilities), a greater economic loss will arise from a breakdown in coordination between the venture and the MNE's other operations (Davidson and McFetridge 1985). This concern, in turn, is likely to motivate the MNE to bargain for its own personnel to control more of the venture's functions. Therefore, 
Chi, Tailan. (1997) The Structuring of Interfirm Exchanges in Business Know-How: Evidence From International Collaborative Ventures. Managerial and Decision Economics, 18, 279-294.

Publisher's Official Version: <http://dx.doi.org/10.1002/(SICI)1099-1468(199706)18:4<279::AID-MDE826>3.0.CO;2-S>.

Open Access Version: http://kuscholarworks.ku.edu/dspace/

H4. The MNE is likely to bear more residual claimancy and hold more residual

control in the venture ceteris paribus when more of the venture's output is

marketed through the MNE's own corporate network.

Finally, there are also theoretical grounds to expect the presence of a positive relationship between a party's share of residual claimancy and its holding of residual control. First, a higher degree of residual control by a party means that it will perform more of the venture's managerial functions, making the profitability of the venture more dependent on its effort (Grossman and Hart 1986). Then, there is likely a greater benefit from giving the party a stronger performance incentive by apportioning it a higher share of residual claimancy in the venture. Second, when one of the parties can easily measure and monitor the performance of the other, that party should also be able to gain control over the other's complementary assets at low costs (Barzel 1989). This condition in turn is likely to result in one of them holding more of both residual control and residual claimancy in the venture.

H5. There exists a positive relationship ceteris paribus between the MNE's bearing of residual claimancy and its holding of residual control in the venture.

\section{EMPIRICAL PROCEDURES}

This section explains the data and the econometric methods used in our study. Empirical investigation of our research questions requires detailed information about the nature of the business arrangements between the parties involved in the exchange. We were fortunate to be given access to a set of contracts and related documents on international collaborative ventures (ICVs) at the United Nations Center on Transnational Corporations. Although we had access to over two hundred of such contracts, only 93 of them were found usable because many of the 
Chi, Tailan. (1997) The Structuring of Interfirm Exchanges in Business Know-How: Evidence From International Collaborative Ventures. Managerial and Decision Economics, 18, 279-294.

Publisher's Official Version: <http://dx.doi.org/10.1002/(SICI)1099-1468(199706)18:4<279::AID-MDE826>3.0.CO;2-S>.

Open Access Version: http://kuscholarworks.ku.edu/dspace/

contracts did not contain enough information for this study. Each of the 93 ICVs in our sample

had exactly two participants: one MNE from an industrialized country and one privately-owned

local firm from the host developing country. In every case the MNE was expected to transfer

some business know-how to the local firm as per the contractual agreements between the two

parties. The years of venture formation ranged from 1965 to 1980, and every effort was made to

ensure that the information on each of the ICVs was current in the year when it was first set up.

As will be explained below, the data extracted from the contracts and related documents (such as memoranda of understanding) were supplemented by information from other archival sources.

\section{A. Variables}

The exact definitions of the variables used in our empirical model are presented in the Appendix. Here, we just give a brief explanation for each of the variables.

The variable SHARE measures the MNE's share of residual claimancy in the venture. If the venture involved equity ownership, the variable was taken as the MNE’s share of equity, adjusted for the effect of any fee that is paid to a party on the basis of the venture's accounting profit (such as a management fee). ${ }^{8}$ If the venture did not involve equity ownership (such as in a contractual joint venture), the variable was taken as the MNE's share of the venture's accounting profit as specified in the contract between the two parties. The value of the variable was set to zero (one) if the MNE (local firm) did not own any equity share in the venture and was not paid any fee on the basis of the venture's accounting profit. ${ }^{9}$

\footnotetext{
${ }^{8}$ When screening the contracts for our sample, we encountered two contracts that used nonlinear sharing rules by which the MNE's compensation is specified as a step function of the venture's accounting profit. As the effect of such a sharing rule is likely to be different from a linear sharing rule (Holmstrom 1982), we did not include the two cases in the sample.

${ }^{9}$ It should be noted that this definition of residual share does not take into account any side payments (e.g., royalties paid to or mandated purchases from either party) even though such payments may vary with some components of the venture's account profit (e.g., sales). Their exclusion from our calculation of the residual share is mainly due to the
} 
Chi, Tailan. (1997) The Structuring of Interfirm Exchanges in Business Know-How: Evidence From International Collaborative Ventures. Managerial and Decision Economics, 18, 279-294.

Publisher's Official Version: <http://dx.doi.org/10.1002/(SICI)1099-1468(199706)18:4<279::AID-MDE826>3.0.CO;2-S>.

Open Access Version: http://kuscholarworks.ku.edu/dspace/

The variable CONTROL measures the degree of control that the MNE held over decision making in the venture. The basic rationale for our specification of this variable is that holding key managerial positions in the venture conveys a more effective means of control than holding only some contractual rights of control and that occupying more of the key positions provides a party with greater control. ${ }^{10}$ By hypothesis five (H5), SHARE and CONTROL were expected to have a positive partial effect on each other after controlling the effects of the other variables.

The variable TRAINING measures the extent of discretionary training that the MNE was expected to provide for the local firm's personnel. The definition of this variable emphasizes training whose outcome depended on the effort of the MNE but was difficult for the local firm to influence. We expect that training conducted at the venture's own facility in the host country would be more dependent on the effort of the MNE and less subject to the influence of the local firm than training conducted at another established production facility of the MNE's elsewhere. In addition, we also expect that, when the training is conducted at a dedicated training facility, the training program normally would be routinized so that the MNE's effort is unlikely to make a very significant difference. Based on $\mathrm{H} 1$, this variable was expected to have a positive partial effect on SHARE and a negative partial effect on CONTROL.

The variable SIMILARITY is intended to reflect the similarity of the local firm's original business to that of the MNE's unit involved in the ICV. The definition of this variable is based on the premise that groupings in the SIC codes provide at least some useful information about the

lack of information that can be used as the basis for converting them to a measure consistent with the share of equity or accounting profit. If we assume that the two parties choose an output level such that the profit of the venture is maximized, then it is theoretically possible to derive a conversion formula based on the knowledge of the venture's cost and revenue functions. Since this knowledge was not available for any of the 93 ventures, we had no way to make a theoretically justifiable conversion and thus decided not to incorporate side payments in the calculation of the residual share. Although this treatment can potentially lead to some biases in the measure of the residual share, we feel that other possible treatments are likely to result in even greater biases. 
Chi, Tailan. (1997) The Structuring of Interfirm Exchanges in Business Know-How: Evidence From International Collaborative Ventures. Managerial and Decision Economics, 18, 279-294.

Publisher's Official Version: <http://dx.doi.org/10.1002/(SICI)1099-1468(199706)18:4<279::AID-MDE826>3.0.CO;2-S>.

Open Access Version: http://kuscholarworks.ku.edu/dspace/

similarity between two businesses. By H2, the variable was expected to have a negative partial effect on SHARE and have a positive partial effect on CONTROL.

The variable PROTECTION is intended to reflect the extent of imperfection in the host country's legal system in terms of its protection for industrial property rights at the time of the venture's formation. The coding of this variable was based on the evaluations given by Business International Corporation (1965-1980). The variable was expected to have a positive partial effect on CONTROL by H3 and was not expected to have any direct effect on SHARE.

The variable MARKETING measures the approximate proportion of the venture's output sold through the MNE's own network. We used a four-level ordinal scale to code this variable because many of the contracts only gave very rough specifications in this regard. Based on H4, the variable was expected to have a positive partial effect on both SHARE and CONTROL.

Because some of the host countries had policies of restricting foreign equity participation or use of expatriate personnel at the time of venture formation, we also introduced two variables to control for the effects of such government intervention. The variable EQUITYRES is intended to measure the restrictiveness of the host country’s policy toward foreign equity ownership. This variable was expected to have a negative partial effect on the MNE's share of residual claimancy since equity sharing was used by many of the ventures to apportion the residuals between the two parties. Although the variable could also affect the MNE's relative control through its effect on the MNE's equity share, we do not expect it to have a direct effect on the MNE's residual control in the presence of the second control variable in our empirical model.

The second control variable is PERSONNELRES, intended to capture the effect of restrictions that the host government placed on the use of expatriate personnel in ICVs. Unlike

\footnotetext{
${ }^{10}$ As will be discussed later in this section, it is possible to test whether the ordering of this variable’s seven
} 
Chi, Tailan. (1997) The Structuring of Interfirm Exchanges in Business Know-How: Evidence From International Collaborative Ventures. Managerial and Decision Economics, 18, 279-294.

Publisher's Official Version: <http://dx.doi.org/10.1002/(SICI)1099-1468(199706)18:4<279::AID-MDE826>3.0.CO;2-S>.

Open Access Version: http://kuscholarworks.ku.edu/dspace/

restrictions on foreign equity ownership, restrictions on foreign managerial control are often not fully reflected in the initial control structure because of difficulty to find qualified natives of the host country to fill certain key positions in the beginning of the venture. The host government often instead requires the ICV to set up a schedule for replacing the MNE's expatriate personnel with the local firm's personnel in a graduated manner (United Nations Center on Transnational Corporations 1978). As the anticipation of future changes in the venture's control structure might also weaken the rationale for giving the MNE a high degree of risk bearing, this variable was expected to have a negative partial effect on both the MNE's residual claimancy and its residual control.

\section{B. Specification and Estimation of the Empirical Model}

As the objective of this study is to explain interfirm arrangements along two distinct but mutually correlated structural dimensions, we decided to use a simultaneous-equation regression model for our empirical analysis. The specification of the two regression equations, based on the theoretical relationships explained earlier, is presented in Table 1. Note that PROTECTION is excluded from the first equation and EQUITYRES is excluded from the second equation on the basis of the hypotheses derived in the last section and the explanations provided in the earlier part of this section. Given that one exogenous variable is excluded from each equation, the two equations are exactly identified.

As specified in Table 1, SHARE and CONTROL are the two endogenous variables of the simultaneous-equation model. Because of the way in which these two variables are measured, we might get a biased estimation if the ordinary-least-squares (OLS) procedure were used to estimate the model. First, as explained earlier, the value of SHARE is bounded between zero and one. If 
Chi, Tailan. (1997) The Structuring of Interfirm Exchanges in Business Know-How: Evidence From International Collaborative Ventures. Managerial and Decision Economics, 18, 279-294.

Publisher's Official Version: <http://dx.doi.org/10.1002/(SICI)1099-1468(199706)18:4<279::AID-MDE826>3.0.CO;2-S>.

Open Access Version: http://kuscholarworks.ku.edu/dspace/

the observations contain a large number of zeros or ones, its distribution will have a spike at the lower or upper bound. In such cases, the OLS procedure is known to produce biased estimates, and unbiased estimation requires the use of a tobit procedure (Maddala 1983). In our model, the equation that has SHARE on its left hand side should ideally be estimated under a two-limit tobit model because the variable is theoretically censored on both ends. But as suggested by Nelson and Olson (1978), if one of the extreme values has only a small number of observations, a onelimit tobit model should still produce basically unbiased estimates. In our sample, SHARE has the value of zero in $41 \%$ of the cases and has the value of one in only $3 \%$ of the cases. Since the extent of censoring from above is negligible, we estimated the equation under a one-limit tobit procedure due to estimation difficulties arising from the simultaneity between the two equations.

The left-hand-side variable of the second regression equation (i.e., CONTROL) is strictly speaking an ordered categorical variable. Since the interval between the categories of this ordinal measure may not correctly reflect that of the underlying continuous variable, the OLS procedure may yield biased estimates, and the ordered probit procedure has been suggested to correct for potential estimation biases (Maddala 1983). In the meantime, the concern over such biases in our case is to some extent mitigated by the fact our measure of CONTROL contains a relatively large number of categories (7) and is defined symmetrically around the center-the category of equal control (see the Appendix). Because of difficulties in estimating a simultaneous-equation model that incorporates both the tobit and ordered probit procedures, we decided to rely on the OLS procedure to estimate the second regression equation. We did, nevertheless, perform an ordered probit estimation of this equation without assuming the simultaneity to test whether a different ordering of the variable's categories would have a better fit to the data. 
Chi, Tailan. (1997) The Structuring of Interfirm Exchanges in Business Know-How: Evidence From International Collaborative Ventures. Managerial and Decision Economics, 18, 279-294.

Publisher's Official Version: <http://dx.doi.org/10.1002/(SICI)1099-1468(199706)18:4<279::AID-MDE826>3.0.CO;2-S>.

Open Access Version: http://kuscholarworks.ku.edu/dspace/

In summary, the econometric model we adopted for this study has both a tobit model and an OLS model embedded in a simultaneous-equation model. This model was initially proposed by Nelson and Olson (1978) and was further developed by Amemiya (1979). The computer codes that we employed to estimate the model were suggested by Greene (1992: 686-687) based on a two-stage method. ${ }^{11}$ The regression results are reported in the next section.

\section{RESULTS}

Table 2 presents the results of our regression analysis. The two middle columns of the table report the regression coefficients estimated under the simultaneous-equation model. The rightmost column of the table reports the regression coefficients estimated under a binomial logit model, whose dependent variable was set to zero if the MNE had no ownership interest in the venture and set to one otherwise. The logit regression results are provided here for comparison purposes because many studies adopted a dichotomous measure of venture structures and used the logit procedure in their regression analyses. It is, however, the simultaneous-equation model that represents the appropriate statistical method for testing the hypotheses of this study. The likelihood ratio test shows that each of the regression equations is significant at the 0.01 level.

As can be seen in Table 2, the extent of discretionary TRAINING that the MNE was expected to provide for the local firm's personnel has a significant impact on both SHARE and CONTROL. The sign of its coefficient in equation 1 indicates that the venture partners tended to give the MNE greater residual claimancy to alleviate the potential moral hazard problem in the provision of such training. The negative sign of its coefficient in equation 2 suggests that training might be used as a measure to substitute locals for the more costly expatriates in such ventures.

\footnotetext{
11The codes given in Greene (1992: 686-687) contain several errors that would result in an incorrect estimation of the covariance matrix. Information regarding how to correct the errors can be obtained from the first author of this
} 
Chi, Tailan. (1997) The Structuring of Interfirm Exchanges in Business Know-How: Evidence From International Collaborative Ventures. Managerial and Decision Economics, 18, 279-294.

Publisher's Official Version: <http://dx.doi.org/10.1002/(SICI)1099-1468(199706)18:4<279::AID-MDE826>3.0.CO;2-S>.

Open Access Version: http://kuscholarworks.ku.edu/dspace/

The fact that the coefficients of this variable have opposite signs in the two regression equations shows that there is a degree of independence between the apportionment of residual claimancy and the assignment of residual control in an interfirm arrangement.

The SIMILARITY of the local firm's business to that of the MNE's unit involved in the venture also has a significant effect on both SHARE and CONTROL. As expected, the variable's coefficient in equation 1 has a negative sign, suggesting that the local firm's prior experience in a technologically similar business might enable it to acquire more of the MNE's know-how via “active learning”, thus reducing the importance of the MNE’s effort in training. The positive sign of the variable's coefficient in equation 2 confirms our hypothesis that the MNE was likely to hold more residual control over the venture's operation when the local firm appeared better able to absorb the MNE's know-how and gain its technological independence. The opposing effects of this variable on SHARE and CONTROL again suggest that the two dimensions of the venture structure might be adjusted in a differentiated manner to remedy different types of transaction cost problems.

The negative sign of the variable PROTECTION in equation 2 indicates that the MNE tended to seek greater residual control in the venture when the protection that the host country's legal regime afforded to industrial property rights appeared to be weaker. As explained earlier, by gaining greater residual control in the venture, the MNE might be able to withhold a key subset of its know-how and retain more effective control over the use of its rent-earning assets.

Although the coefficients of MARKETING have the predicted signs in both regression equations, only one of the coefficients is statistically significant. As the variable measures the portion of the venture's output sold via the MNE's own network, its positive sign in equation 1 
Chi, Tailan. (1997) The Structuring of Interfirm Exchanges in Business Know-How: Evidence From International Collaborative Ventures. Managerial and Decision Economics, 18, 279-294.

Publisher's Official Version: <http://dx.doi.org/10.1002/(SICI)1099-1468(199706)18:4<279::AID-MDE826>3.0.CO;2-S>.

Open Access Version: http://kuscholarworks.ku.edu/dspace/

confirms our hypothesis that the benefit from the local firm's residual bearing would be lower when its marketing effort appeared less important to the venture.

We have earlier hypothesized that the residual claimancy and residual control of a party would exert a positive effect on each other after the effects of other variables are controlled for. It is surprising that the effect of CONTROL on SHARE is not statistically significant, despite the highly significant positive effect of SHARE on CONTROL. This result may reflect the policy of “unbundling” that was popular in the developing world until the late 1980s (Hennart 1989). The policy was based on the supposition that developing countries would be more successful in gaining economic independence by restricting foreign equity ownership in technology transfer arrangements. Because it was often difficult to find professionally qualified natives to fill key technical and managerial positions in the venture, MNE was often given substantial managerial control over the venture's operation without being a major equity holder. A review of the ICV contracts used in our sample reveals that some of the ventures did have this type of arrangements.

Another surprise in the regression results relates to the effect of the host country’s policy toward the use of expatriate personnel (PERSONNELRES) in ICVs. Despite expectation to the contrary, this variable has a significant positive coefficient in equation 1 . It suggests that the MNE were likely given a greater share of residual claimancy when the host government had a policy of restricting the use of expatriate personnel, with other things held equal. This finding may reflect the way in which such a policy is often implemented. Faced with a shortage of qualified natives in the country, the host government often had to accept substantial foreign managerial control in the beginning of the venture and required a gradual shift of managerial control and equity ownership to the local firm. The knowledge of such scheduled changes in the 
Chi, Tailan. (1997) The Structuring of Interfirm Exchanges in Business Know-How: Evidence From International Collaborative Ventures. Managerial and Decision Economics, 18, 279-294.

Publisher's Official Version: <http://dx.doi.org/10.1002/(SICI)1099-1468(199706)18:4<279::AID-MDE826>3.0.CO;2-S>.

Open Access Version: http://kuscholarworks.ku.edu/dspace/

venture might make the host government more willing to accept a higher initial equity share for the MNE than otherwise (De la Torre 1981).

As noted earlier, existent studies have generally used a binomial logit model (BLM) to investigate the problem of institutional choice in interfirm exchanges of business know-how, and a simultaneous-equation model (SEM) would allow a richer and less ambiguous analysis of this research question. We can illustrate the informational advantages of the SEM by performing a similar analysis of our data under the more traditional BLM (see Table 2). First, the BLM only permits inferences about a variable's effect on the likelihood for the MNE to have equity participation in the venture; the SEM, however, allows direct inferences about a variable's effect on the more elaborately defined venture structure. Furthermore, the regression coefficient of an exogenous variable in the SEM represents its effect on the dependent variable in the regression equation after controlling for the potential reciprocal effects of the two endogenous variables on each other. This reveals detailed information about the trade-offs involved in the negotiation of the ICV structure that is not possible to obtain under the BLM. Take the similarity of the local firm's business to that of the MNE's unit involved in the venture, for instance. Under the SEM, it is found to have a negative partial effect on the MNE's residual share and a positive partial effect on the MNE's residual control. Under the BLM, however, it is impossible to see the variable's opposing effects on the two different dimensions of the ICV structure. Because the SEM more fully utilizes the available information on the venture structure, the statistical significance of the exogenous variables also tends to be higher in the SEM than in the BLM. It is interesting to note that every exogenous variable is significant the 0.05 level in at least one of the equations under the SEM while only two of them reach this level of statistical significance under the BLM. 
Chi, Tailan. (1997) The Structuring of Interfirm Exchanges in Business Know-How: Evidence From International Collaborative Ventures. Managerial and Decision Economics, 18, 279-294.

Publisher's Official Version: <http://dx.doi.org/10.1002/(SICI)1099-1468(199706)18:4<279::AID-MDE826>3.0.CO;2-S>.

Open Access Version: http://kuscholarworks.ku.edu/dspace/

We also performed ordered probit and OLS estimations of the second equation without embedding it in a simultaneous-equation model. The results of these estimations, given in Table 3, can serve two purposes. The first is to test whether our data provide any empirical support for the way in which we ranked the different categories of the variable CONTROL, and the other is to shed some light on the extent of difference between the ordered probit and OLS estimates.

As explained earlier, a basic assumption for our adopted ordering of the seven categories identified for the variable CONTROL is that holding key managerial positions in the venture conveys a more effective means of control than holding only some contractual rights of control. One may test this assumption by reversing the ranking of some of the categories and finding out whether the recoded variable is better explained statistically by the regression than the originally coded variable (via a comparison of their respective log likelihood functions). ${ }^{12}$ We conducted such a test by reversing the order of categories 1 and 2 and the order of categories 4 and 5 , since the ranking of these two pairs of adjacent categories seems to be subject to more uncertainty than any other pairs. As shown by the results of both the ordered probit and OLS regressions in Table 3 , the recoded variable is not as well explained by the regression as the originally coded variable based on the values of the log likelihood functions. The existence of such differences provides some support for the ordering specified in the Appendix, even though their magnitudes are quite small (which could be due to the roughness of our measurement).

A comparison of the ordered probit estimates with the OLS estimates reveals that the two alternative estimation procedures do not result in markedly different estimates under the singleequation formulation. It is, however, interesting to see that the endogenous variables show a

\footnotetext{
${ }^{12}$ We thank an anonymous referee for suggesting this method of testing the ordering of the different categories in the variable CONTROL.
} 
Chi, Tailan. (1997) The Structuring of Interfirm Exchanges in Business Know-How: Evidence From International Collaborative Ventures. Managerial and Decision Economics, 18, 279-294.

Publisher's Official Version: <http://dx.doi.org/10.1002/(SICI)1099-1468(199706)18:4<279::AID-MDE826>3.0.CO;2-S>.

Open Access Version: http://kuscholarworks.ku.edu/dspace/

much lower level of statistical significance when the simultaneity between the two equations is removed (as can be seen from the OLS estimates for the second equation in Tables 2 and 3).

\section{CONCLUDING REMARKS}

As Alchian and Woodward (1988) noted in their review article, economic studies on the efficiency of contracting progressed for a long time along two largely separate lines. One line of inquiry focused on the difficulty of performance measurement and pointed to the design of the compensation structure as a key contracting mechanism. The other line of inquiry, meanwhile, focused on the problem of asset specificity and pointed to the design of the control structure as a key contracting mechanism. Although more recent theoretical work has suggested that these two dimensions of the contractual structure represent two distinct but interdependent mechanisms, few studies have distinguished them empirically. ${ }^{13}$ Our study is one of the first to perform an empirical analysis of interfirm exchange arrangements along these two structural dimensions.

As discussed in the preceding section, the two-dimensional framework for analyzing the structure of interfirm exchanges received clear support from our regression analysis. In an earlier study, Gatignon and Anderson (1988) also hypothesized the control structure of joint ventures to be a function of transaction cost considerations, but their regression results did not provide clear support for this hypothesis. ${ }^{14}$ Although they recognized the potential for significant deviations of a party’s managerial control from its equity ownership, due to the lack of access to more accurate information, they measured the MNE’s control in joint ventures as a multinomial variable based

\footnotetext{
${ }^{13}$ See, for example, the theoretical models of Grossman and Hart (1986), Holmstrom and Milgrom (1990) and Masten (1988).

${ }^{14}$ In the meantime, their study found strong empirical support for the hypothesis that the MNE's choice between partnering and going it alone is a function of transaction cost considerations.
} 
Chi, Tailan. (1997) The Structuring of Interfirm Exchanges in Business Know-How: Evidence From International Collaborative Ventures. Managerial and Decision Economics, 18, 279-294.

Publisher's Official Version: <http://dx.doi.org/10.1002/(SICI)1099-1468(199706)18:4<279::AID-MDE826>3.0.CO;2-S>.

Open Access Version: http://kuscholarworks.ku.edu/dspace/

on its share of equity. In addition, their regression analysis was performed under a multinomial logit model that did not presume the dependent variable to have a consistent rank-ordering.

Because it is normally difficult to obtain direct measures of transaction costs such as the potential loss from shirking or holdup, empirical studies (including this one) are generally forced to use proxies that tend to represent more than one type of transaction cost considerations. Since moral hazard and holdup tend to be addressed by adjustments in the two different dimensions of the contracting structure, a proxy variable could a priori affect both of the structural dimensions and might even influence them in opposite directions. Then, it might be rather easy to put forth contradicting arguments about the effect of a proxy variable when the contracting structure is measured by a single variable that is correlated with both types of the structural arrangements. The empirical methods developed in this study can help reduce such ambiguity and potentially benefit future studies on the contracting structure of bilateral exchanges. 


\section{APPENDIX}

Definitions of Variables

\begin{tabular}{|c|c|c|c|}
\hline Variable & Definition & Mean & s.d. \\
\hline $\begin{array}{l}\text { SHARE } \\
\text { (source of data: a) }\end{array}$ & = the MNE's percentage share of the venture's accounting profit & 0.34 & 0.34 \\
\hline $\begin{array}{l}\text { CONTROL } \\
\text { (source of data: a) }\end{array}$ & $\begin{array}{l}=0 \text { if the local firm's personnel held all the key managerial positions in the venture and was not } \\
\text { constrained by contract to obtain the MNE's consent on any major managerial decisions } \\
=1 \text { if the local firm's personnel held all the key managerial positions in the venture but was } \\
\text { constrained by contract to obtain the MNE's consent on some important managerial decisions } \\
=2 \text { if the local firm's personnel held a majority of the key managerial positions in the venture, } \\
\text { with the MNE's personnel holding a minority of such positions } \\
=3 \text { if the key managerial positions in the venture were divided roughly equally between the local } \\
\text { firm and the MNE } \\
=4 \text { if the MNE's personnel held a majority of the key managerial positions in the venture, with } \\
\text { the local firm's personnel holding a minority of such positions } \\
=5 \text { if the MNE's personnel held all the key managerial positions in the venture but was constrain- } \\
\text { ed by contract to obtain the local firm's consent on some important managerial decisions } \\
=6 \text { if the MNE's personnel held all the key managerial positions in the venture and was not } \\
\text { constrained by contract to obtain the local firm's consent on any major managerial decisions }\end{array}$ & 1.66 & 1.10 \\
\hline $\begin{array}{l}\text { TRAINING } \\
\text { (source of data: a) }\end{array}$ & $\begin{array}{l}=0 \text { if the MNE was not required or expected to provide any training for the local firm's personnel } \\
=1 \text { if the MNE was required or expected to provide some training for the local firm's personnel at } \\
\text { a dedicated training facility that it owned and operated } \\
=2 \text { if the MNE was required or expected to provide some training for the local firm's personnel at } \\
\text { a production facility that it owned and operated } \\
=3 \text { if the MNE was required or expected to devise and implement a training program for the local } \\
\text { firm's personnel in the host country }\end{array}$ & 1.73 & 1.19 \\
\hline
\end{tabular}

Source of data: $\mathrm{a}=$ the written contracts and memoranda of understanding between the collaborating parties; $\mathrm{b}=\mathrm{Business}$ International Corp. (1965-1980); c = U.S. Department of Commerce (1965-1980). 


\section{APPENDIX continued}

Definitions of Variables

\begin{tabular}{|c|c|c|c|}
\hline Variable & Definition & Mean & s.d. \\
\hline $\begin{array}{l}\text { SIMILARITY } \\
\text { (source of data: a) }\end{array}$ & $\begin{array}{l}=0 \text { if the SIC code of the local firm's business and the SIC code of the MNE's unit involved in } \\
\text { the venture belong to different product/service groups } \\
=1 \text { if the } 3 \text {-digit SIC code of the local firm's business and the 3-digit SIC code of the MNE's unit } \\
\text { involved in the venture are different but their first } 2 \text { digits are the same } \\
=2 \text { if the 4-digit SIC code of the local firm's business and the 4-digit SIC code of the MNE's unit } \\
\text { involved in the CV are different but their first } 3 \text { digits are the same } \\
=3 \text { if the } 4 \text {-digit SIC code of the local firm's business and the } 4 \text {-digit SIC code of the MNE's unit } \\
\text { involved in the CV are the same }\end{array}$ & 1.56 & 1.04 \\
\hline $\begin{array}{l}\text { PROTECTION } \\
\text { (source of data: b) }\end{array}$ & $\begin{array}{l}=0 \text { if the host country's legal system was rated by Business International Corp. as above average } \\
\text { among developing countries with regard to its protection of foreign-owned industrial property } \\
=1 \text { if the host country's legal system was rated by Business International Corp. as about average } \\
\text { among developing countries with regard to its protection of foreign-owned industrial property } \\
=2 \text { if the host country's legal system was rated by Business International Corp. as below average } \\
\text { among developing countries with regard to its protection of foreign-owned industrial property }\end{array}$ & 0.47 & 0.73 \\
\hline $\begin{array}{l}\text { MARKETING } \\
\text { (source of data: a) }\end{array}$ & $\begin{array}{l}=0 \text { if the MNE was not expected to market any of the venture's output via its own network } \\
=1 \text { if the MNE was expected to market about } 1 / 4 \text { of the venture's output via its own network } \\
=2 \text { if the MNE was expected to market about } 1 / 2 \text { of the venture's output via its own network } \\
=3 \text { if the MNE was expected to market about } 3 / 4 \text { of the venture's output via its own network }\end{array}$ & 0.30 & 0.79 \\
\hline $\begin{array}{l}\text { EQUITYRES } \\
\text { (source of data: b,c) }\end{array}$ & $\begin{array}{l}=0 \text { if the host country did not normally restrict foreign equity participation } \\
=1 \text { if the host country generally expected some local ownership but did not require local majority } \\
=2 \text { if the host country usually required local majority ownership } \\
=3 \text { if the host country discouraged foreign equity participation without prohibiting it entirely }\end{array}$ & 1.74 & 0.93 \\
\hline $\begin{array}{l}\text { PERSONNELRES } \\
\text { (source of data: b,c) }\end{array}$ & $\begin{array}{l}=0 \text { if the screening authorities of the host country generally did not restrict foreign investors from } \\
\text { putting their own personnel in key managerial positions } \\
=1 \text { otherwise }\end{array}$ & 0.73 & 0.45 \\
\hline
\end{tabular}


Chi, Tailan. (1997) The Structuring of Interfirm Exchanges in Business Know-How: Evidence From International Collaborative Ventures. Managerial and Decision Economics, 18, 279-294.

Publisher's Official Version: <http://dx.doi.org/10.1002/(SICI)1099-1468(199706)18:4<279::AID-MDE826>3.0.CO;2-S>.

Open Access Version: http://kuscholarworks.ku.edu/dspace/

\section{REFERENCES}

A.A. Alchian and S. Woodward (1988). The firm is dead; long live the firm. Journal of Economic Literature, 116, 65-79.

T. Amemiya (1979). The estimation of a simultaneous-equation tobit model. International Economic Review, 20, 169-181.

Y. Barzel (1989). Economic Analysis of Property Rights, Cambridge, U.K.: Cambridge University Press.

P.W. Beamish (1988). Multinational Joint Ventures in Developing Countries, London, U.K.: Routledge.

P.W. Beamish and J.C. Banks (1987). Equity joint ventures and the theory of the multinational enterprise. Journal of International Business Studies, 18, 1-16.

R.P. Benko (1987). Protecting Intellectual Property Rights: Issues and Controversies, Washington, D.C.: American Enterprise Institute for Public Policy Research.

S. Balakrishnan and M.P. Koza (1993). Information asymmetry, adverse selection and joint ventures: Theory and evidence. Journal of Economic Behavior and Organization, 20: 99-117.

Business International Corp. (1965-1980). Investing, Licensing And Trading Conditions Abroad, New York: Business International Corporation.

T. Chi (1996). Performance verifiability and output sharing in collaborative ventures. Management Science, 42: 93-109.

F.J. Contractor (1985). Licensing in International Strategy : A Guide for Planning and Negotiations, Westport, CN: Quorum Books.

F.J. Contractor and P. Lorange, (1987). Why should firms cooperate? The strategy and economic basis for cooperate ventures. In Cooperative Strategies in International Business (edited by F.J. Contractor \& P. Lorange), Lexington, MA: Lexington Books, pp. 3-28.

K.J. Crocker and S.E. Masten (1991). Pretia ex machina? Prices and process in long-term contracts. Journal of Law \& Economics, 34, 69-99.

W.H. Davidson and D.G. McFetridge. (1985). Key characteristics in the international technology transfer mode. Journal of International Business Studies, 16, Summer, 5-21.

J. de la Torre (1981). Foreign investment and economic development: Conflict and negotiation. Journal of International Business Studies, 12, Fall, 9-32.

M. Eswaran and A. Kotwal. (1985). A theory of contractual structure in agriculture. American Economic Review, 75, 352-367. 
Chi, Tailan. (1997) The Structuring of Interfirm Exchanges in Business Know-How: Evidence From International Collaborative Ventures. Managerial and Decision Economics, 18, 279-294.

Publisher's Official Version: <http://dx.doi.org/10.1002/(SICI)1099-1468(199706)18:4<279::AID-MDE826>3.0.CO;2-S>.

Open Access Version: http://kuscholarworks.ku.edu/dspace/

H. Gatignon and E. Anderson. (1988). The multinational corporation's degree of control over foreign subsidiaries: An empirical test of a transaction cost explanation. Journal of Economics, Law and Organization, 4, 305-336.

J.M. Geringer and L. Herbert (1989). Control and performance of international joint ventures. Journal of International Business Studies, 20, 235-253.

V.P. Goldberg and J.R. Erickson (1987). Quantity and price adjustment in long-term contracts: A case study of petroleum coke. Journal of Law \& Economics, 30, 369-398.

B. Gomes-Casseres (1989). Ownership structures of foreign subsidiaries. Journal of Economic Behavior and Organization, 11, 1-25.

W.H. Greene (1992). LIMDEP: User's Manual and Reference Guide, Bellport, NY: Econometric Software, Inc.

S.J. Grossman and O.D. Hart. (1986). The costs and benefits of ownership: A theory of vertical and lateral integration. Journal of Political Economy, 94, 691-719.

G. Hamel, Y. Doz and C.K. Prahalad (1989). Collaborate with your competitors-and win. Harvard Business Review, 67, January-February, 133-139.

J.-F. Hennart (1988). A transaction cost theory of equity joint ventures. Strategic Management Journal, 9, 361-374.

J.-F. Hennart (1989). Can 'new forms of investment' substitute for the old forms? A transactions cost perspective. Journal of International Business Studies, 20, 211-234.

J.-F. Hennart (1991). The transaction costs theory of joint ventures: An empirical study of Japanese subsidiaries in the United States. Management Science, 37, 483-497.

B. Holmstrom (1982). Moral hazard in teams. Bell Journal of Economics, 13, 324-340.

B. Holmstrom and P. Milgrom. (1990). Regulating trade among agents. Journal of Institutional and Theoretical Economics, 146, 85-105.

P.L. Joskow (1985). Vertical integration and long-term contracts: The case of coal-burning electric generating plants. Journal of Law, Economics and Organization, 1, 33-80.

B. Klein (1992). Contracts and incentives: The role of contract terms in assuring performance. In Contract Economics (edited by L. Werin and H. Wijkander), Oxford, UK: Blackwell, pp. 149172.

B. Kogut (1988). Joint ventures: Theoretical and empirical perspectives. Strategic Management Journal, 9, 319-332.

S. Lippman and R.P. Rumelt (1982). Uncertain imitability: An analysis of interfirm differences in efficiency under competition. Bell Journal of Economics, 13, 418-438. 
Chi, Tailan. (1997) The Structuring of Interfirm Exchanges in Business Know-How: Evidence From International Collaborative Ventures. Managerial and Decision Economics, 18, 279-294.

Publisher's Official Version: <http://dx.doi.org/10.1002/(SICI)1099-1468(199706)18:4<279::AID-MDE826>3.0.CO;2-S>.

Open Access Version: http://kuscholarworks.ku.edu/dspace/

J. McManus (1975). The cost of alternative economic organizations. Canadian Journal of Economics, 75, 334-340.

G.S. Maddala (1983). Limited-Dependent and Qualitative Variables in Econometrics, Cambridge, U.K.: Cambridge University Press.

S.E. Masten (1988). Equity, opportunism, and the design of contractual relations. Journal of Institutional and Theoretical Economics, 144, 180-195.

F. Nelson and L. Olson. (1978). Specification and estimation of a simultaneous-equation model with limited dependent variables. International Economic Review, 19, 695-709.

R. Nelson and S. Winter (1982). An Evolutionary Theory of Economic Change, Cambridge, MA: Harvard University Press.

E.T. Penrose (1959). The Theory of the Growth of the Firm. Oxford: Blackwell.

G.P. Pisano (1989). Using equity participation to support exchange: Evidence from the biotechnology industry. Journal of Law, Economics and Organization, 5, 109-126.

W. Shan (1990). An empirical analysis of organizational strategies by entrepreneurial hightechnology firms. Strategic Management Journal, 11, 129-139.

D.J. Teece (1982). Towards an economic theory of the multiproduct firm. Journal of Economic Behavior and Organization, 3, 39-63.

D.J. Teece (1986). Profiting from technological innovation: Implications for integration, collaboration, licensing and public policy. Research Policy, 15, 285-305.

United Nations Center on Transnational Corporations (1978). National Legislation and Regulations Relating to Transnational Corporations, New York: United Nations.

U.S. Department of Commerce (1965-1980). Overseas business report, Washington, DC: U.S. Government Printing Office.

O.E. Williamson (1975). Markets and Hierarchies: Analysis and Antitrust Implications, New York: Free Press.

O.E. Williamson (1985). The Economic Institutions of Capitalism, New York: Free Press. 
Chi, Tailan. (1997) The Structuring of Interfirm Exchanges in Business Know-How: Evidence From International Collaborative Ventures. Managerial and Decision Economics, 18, 279-294.

Publisher's Official Version: <http://dx.doi.org/10.1002/(SICI)1099-1468(199706)18:4<279::AID-MDE826>3.0.CO;2-S>.

Open Access Version: http://kuscholarworks.ku.edu/dspace/

TABLE 1

Specification of the Two Simultaneous Regression Equations

\begin{tabular}{|c|c|c|c|c|}
\hline \multirow[b]{2}{*}{ RHS Variables } & \multicolumn{2}{|c|}{$\begin{array}{c}\text { Equation 1: } \\
\text { LHS Variable }=\text { SHARE }\end{array}$} & \multicolumn{2}{|c|}{$\begin{array}{c}\text { Equation 2: } \\
\text { LHS Variable }=\text { CONTROL }\end{array}$} \\
\hline & $\begin{array}{c}\text { Expected Sign of } \\
\text { Regression Coefficient }\end{array}$ & $\begin{array}{l}\text { Hypothesis } \\
\text { Being Tested }\end{array}$ & $\begin{array}{c}\text { Expected Sign of } \\
\text { Regression Coefficient }\end{array}$ & $\begin{array}{l}\text { Hypothesis } \\
\text { Being Tested }\end{array}$ \\
\hline INTERCEPT & ? & & ? & \\
\hline SHARE & N/A & & + & H5 \\
\hline CONTROL & + & H5 & N/A & \\
\hline TRAINING & + & H1 & - & H1 \\
\hline SIMILARITY & - & $\mathrm{H} 2$ & + & $\mathrm{H} 2$ \\
\hline PROTECTION & $0^{\mathrm{a}}$ & & + & H3 \\
\hline MARKETING & + & $\mathrm{H} 4$ & + & $\mathrm{H} 4$ \\
\hline EQUITYRES & - & & $0^{\mathrm{a}}$ & \\
\hline PERSONNELRES & - & & - & \\
\hline
\end{tabular}

${ }^{\mathrm{a}}$ The variable is excluded from the regression equation because it is expected to have no direct effect on the left-hand-side variable when the effects of other variables are controlled for. 
Chi, Tailan. (1997) The Structuring of Interfirm Exchanges in Business Know-How: Evidence From International Collaborative Ventures. Managerial and Decision Economics, 18, 279-294.

Publisher's Official Version: <http://dx.doi.org/10.1002/(SICl)1099-1468(199706)18:4<279::AID-MDE826>3.0.CO;2-S>.

Open Access Version: http://kuscholarworks.ku.edu/dspace/

TABLE 2

Estimated Coefficients from Regression Analysis ${ }^{\mathrm{a}}$

\begin{tabular}{|c|c|c|c|}
\hline \multirow[b]{2}{*}{ RHS Variables } & \multicolumn{2}{|c|}{ Simultaneous-Equation Model ${ }^{\mathrm{b}}$} & \multirow[b]{2}{*}{$\begin{array}{c}\text { Binomial } \\
\text { Logit Model }^{\mathrm{C}}\end{array}$} \\
\hline & $\begin{array}{c}\text { Equation 1: } \\
\text { LHS = SHARE }\end{array}$ & $\begin{array}{c}\text { Equation 2: } \\
\text { LHS = CONTROL }\end{array}$ & \\
\hline INTERCEPT & $\begin{array}{c}0.14 \\
(0.24)\end{array}$ & $\begin{array}{l}1.98 * * * \\
(0.37)\end{array}$ & $\begin{array}{c}0.49 \\
(1.38)\end{array}$ \\
\hline SHARE & & $\begin{array}{l}0.04 * * * \\
(0.01)\end{array}$ & \\
\hline CONTROL & $\begin{array}{c}0.06 \\
(0.05)\end{array}$ & & \\
\hline TRAINING & $\begin{array}{l}0.13^{* * * *} \\
(0.03)\end{array}$ & $\begin{array}{l}-0.40^{* * *} \\
(0.14)\end{array}$ & $\begin{array}{l}1.35 * * * \\
(0.44)\end{array}$ \\
\hline SIMILARITY & $\begin{array}{l}-0.22 * * * \\
(0.05)\end{array}$ & $\begin{array}{l}0.51^{*} \\
(0.26)\end{array}$ & $\begin{array}{l}-1.83^{* * *} \\
(0.48)\end{array}$ \\
\hline PROTECTION & & $\begin{array}{l}0.61 * * * \\
(0.12)\end{array}$ & $\begin{array}{l}-0.39 \\
(0.50)\end{array}$ \\
\hline MARKETING & $\begin{array}{l}0.11 * * \\
(0.05)\end{array}$ & $\begin{array}{c}0.04 \\
(0.18)\end{array}$ & $\begin{array}{l}1.58^{*} \\
(0.73)\end{array}$ \\
\hline EQUITYRES & $\begin{array}{l}-0.10 * * \\
(0.05)\end{array}$ & & $\begin{array}{c}-0.72 * \\
(0.41)\end{array}$ \\
\hline PERSONNELRES & $\begin{array}{l}0.29 * * \\
(0.11)\end{array}$ & $\begin{array}{l}-1.94^{* * *} \\
(0.30)\end{array}$ & $\begin{array}{l}1.82 * \\
(1.07)\end{array}$ \\
\hline
\end{tabular}

${ }^{\mathrm{a}} N=93$. Standard deviation in parentheses. The likelihood ratio test shows that each of the regression equations is significant at the 0.01 level.

${ }^{\mathrm{b}}$ These two columns report the regression coefficients estimated under the simultaneous-equation model. The left-hand-side variable in equation 1 is SHARE and the left-hand-side variable in equation 2 is CONTROL.

${ }^{\mathrm{c}}$ This column reports the regression coefficients estimated under a binomial logit model, where the value of the dependent variable was set to zero if the MNE had no ownership interest in the venture and set to one otherwise.

$$
\begin{gathered}
* p<0.1 \\
* * p<0.05 \\
* * * p<0.01
\end{gathered}
$$


Chi, Tailan. (1997) The Structuring of Interfirm Exchanges in Business Know-How: Evidence From International Collaborative Ventures. Managerial and Decision Economics, 18, 279-294.

Publisher's Official Version: <http://dx.doi.org/10.1002/(SICl)1099-1468(199706)18:4<279::AID-MDE826>3.0.CO;2-S>.

Open Access Version: http://kuscholarworks.ku.edu/dspace/

TABLE 3

Ordered Probit and OLS Estimations of Equation 2 without Simultaneity ${ }^{\mathrm{a}}$

\begin{tabular}{|c|c|c|c|c|}
\hline \multirow[b]{2}{*}{ RHS Variables } & \multicolumn{2}{|c|}{$\begin{array}{l}\text { Adopted Coding of } \\
\text { CONTROL }^{\mathrm{b}}\end{array}$} & \multicolumn{2}{|c|}{$\begin{array}{l}\text { Alternative Coding of } \\
\text { CONTROL }^{\mathrm{b}}\end{array}$} \\
\hline & Ordered Probit & OLS & Ordered Probit & OLS \\
\hline INTERCEPT & $\begin{array}{l}-0.24 \\
(0.59)\end{array}$ & $\begin{array}{l}1.68 * * * \\
(0.60)\end{array}$ & $\begin{array}{l}-0.30 \\
(0.57)\end{array}$ & $\begin{array}{l}1.41^{* *} \\
(0.62)\end{array}$ \\
\hline SHARE & $\begin{array}{l}0.03^{* * * *} \\
(0.01)\end{array}$ & $\begin{array}{l}0.03^{* * *} \\
(0.01)\end{array}$ & $\begin{array}{l}0.03^{* * *} \\
(0.01)\end{array}$ & $\begin{array}{l}0.03 * * * \\
(0.01)\end{array}$ \\
\hline TRAINING & $\begin{array}{l}-0.12 \\
(0.15)\end{array}$ & $\begin{array}{l}-0.17 \\
(0.15)\end{array}$ & $\begin{array}{l}-0.13 \\
(0.14)\end{array}$ & $\begin{array}{l}-0.17 \\
(0.16)\end{array}$ \\
\hline SIMILARITY & $\begin{array}{l}-0.01 \\
(0.20)\end{array}$ & $\begin{array}{c}0.01 \\
(0.19)\end{array}$ & $\begin{array}{l}-0.05 \\
(0.22)\end{array}$ & $\begin{array}{l}-0.02 \\
(0.21)\end{array}$ \\
\hline PROTECTION & $\begin{array}{l}0.52 * * * \\
(0.19)\end{array}$ & $\begin{array}{l}0.65^{* * *} \\
(0.20)\end{array}$ & $\begin{array}{l}0.45^{*} \\
(0.23)\end{array}$ & $\begin{array}{l}0.63^{* * *} \\
(0.21)\end{array}$ \\
\hline MARKETING & $\begin{array}{c}0.13 \\
(0.18)\end{array}$ & $\begin{array}{c}0.28 \\
(0.21)\end{array}$ & $\begin{array}{c}0.01 \\
(0.19)\end{array}$ & $\begin{array}{c}0.11 \\
(0.22)\end{array}$ \\
\hline PERSONNELRES & $\begin{array}{l}-1.14^{* * *} \\
(0.41)\end{array}$ & $\begin{array}{l}-1.62^{* * *} \\
(0.40)\end{array}$ & $\begin{array}{l}-0.95 * * \\
(0.40)\end{array}$ & $\begin{array}{l}-1.29 * * * \\
(0.42)\end{array}$ \\
\hline Log likelihood function & $-101.19 * * *$ & $-159.58 * * *$ & $-102.92 * * *$ & $-162.94^{* * *}$ \\
\hline
\end{tabular}

${ }^{\mathrm{a}} N=93$. Standard deviation in parentheses.

${ }^{\mathrm{b}}$ The adopted coding of CONTROL is specified the Appendix. Under the alternative coding, a party is considered to have less control if it held all the key managerial positions but faced some contractual constraints on its decision making power than if it held only a majority of those key positions and possibly faced no contractual constraints. In other words, the ranking of categories 1 and 2 and the ranking of categories 4 and 5, as defined in the Appendix, are reversed.

$$
\begin{gathered}
* p<0.1 \\
* * p<0.05 \\
* * * p<0.01
\end{gathered}
$$

